\title{
Pengembangan Video Penggunaan Alat Gelas Laboratorium Kimia di Universitas
}

\author{
Khusna Arif Rakhman ${ }^{1}$ *, A. Rasyid Saraha ${ }^{1}$, Nurfatimah Sugrah ${ }^{1}$ \\ ${ }^{1}$ Program Studi Pendidikan Kimia, Fakultas Keguruan dan Ilmu Pendidikan, Universitas Khairun. \\ Jalan Bandara Babullah Kampus I Akehuda, Ternate, Maluku Utara, Indonesia \\ * Corresponding Author. Email: khusna.arif.rakhman@gmail.com
}

Received: 2 September 2017; Revised: 24 October 2017; Accepted: 25 October 2017

\begin{abstract}
Abstrak
Telah dilakukan penelitian tentang pengembangan media video penggunaan alat gelas di Laboratorium pada mahasiswa tahun I Program Studi Pendidikan Kimia, dengan tujuan menghasilkan video penggunaan alat gelas di laboratorium yang layak digunakan sebagai panduan mahasiswa program studi pendidikan kimia FKIP Universitas Khairun dalam melakukan praktikum. Media video pengguaan alat gelas di Laboratorium ini dikembangkan berdasarkan kaidah pengembangan media pembelajaran yang diadaptasi dari tahap pengembangan 4D. Metode pengembangan 4D memiliki 4 tahap pengembangan dinataranya: pendefinisian, perancangan, pengembangan dan penyebaran. Hasil pengembangan berupa video pengenalan dan penggunaan alat gelas di laboratorium dengan durasi 18 menit. Dari segi validitas media video, produk tersebut dinyatakan sangat valid oleh 3 orang validator dengan nilai rata-rata 3,81 dari skala 4 dengan kategori sangat valid. Produk media video juga diukur keterbacaannya oleh 10 mahasiswa prodi pendidikan kimia FKIP Universitas Khairun dengan persentase keterbacaan sebesar 79,17\%. Sedangkan angka keterlaksanaan praktikum menggunakan panduan kedua video tersebut di Laboratorium sebesar 67,50\%.
\end{abstract}

Kata Kunci: Alat gelas laboratorium kimia; metode 4D, pengembangan video

\section{Video Development of Use of Chemical Laboratory Equipment in University}

The research has been conducted to develop of video use of glassware in the laboratory at the first year students of the educational chemistry department, with the aims to produce a video of glass tools usage in a laboratory that was suitable to be used as a practicum module for students of educational chemistry department FKIP Khairun University. Video development methods based on learning media development principles adapted from the $4 D$ development stage. The $4 D$ development method has four development stages: defining, designing, developing and disseminating. The results of the development of a video introduction and use of glassware in the laboratory with a duration of 18 minutes. The validity of product was expressed by 3 validators with an average rating of 3.81 from a scale of 4 with very valid categories. Video products are also measured legibility by 10 students of educational chemistry department FKIP Khairun University with a percentage of legibility of $79.17 \%$. While the practical implementation the video usage on practicum in the Laboratory of $67.50 \%$.

Keywords: 4D method, chemistry laboratory glassware; video development.

How to Cite: Rakhman, K., Saraha, A., \& Sugrah, N. (2017). Pengembangan video penggunaan alat gelas laboratorium kimia di universitas. Jurnal Inovasi Pendidikan IPA, 3(2), 161-171. doi:http://dx.doi.org/10.21831/jipi.v3i2.15667

Permalink/DOI: http://dx.doi.org/10.21831/jipi.v3i2.15667 


\section{PENDAHULUAN}

Seorang kimiawan, termasuk di dalamnya guru kimia di sekolah menengah seharusnya tidak hanya memiliki keterampilan melakukan pengajaran kimia secara teoritis di kelas, namun juga harus mampu merancang dan melaksanakan praktikum kimia di sekolah dengan aman (Ismail, 2016). Proses merancang, melaksanakan dan mengorganisasi praktikum kimia, sangat membutuhkan keterampilan sains laboratorium (Hofstein \& Mamlok-Naaman, 2007). Pembelajaran keterampilan sains seperti menggunakan alat dan bahan kimia di tingkat universitas, sebagian besar dilaksanakan dalam praktikum kimia selama 3 tahun dari 5 tahun masa studi yang direncanakan. Program studi pendidikan kimia FKIP Universitas Khairun, merumuskan penjenjangan keterampilan laboratorium bagi mahasiswa dalam 3 jenjang, yakni: mengenal dan mampu mengoperasikan alat gelas di laboratorium kimia dengan baik dan aman, melakukan preparasi dan pemisahan kimia, dan mampu melakukan kegiatan analisis dan sintesis bahan kimia. Dengan adanya penjenjangan ini diharapkan mampu menumbuhkan kreatifitas dan keterampilan sains mahasiswa pendidikan kimia untuk merumuskan dan menyusun pembelajaran kimia di sekolah menengah.

Minimnya jam praktikum karena alasan keterbatasan alat dan bahan kimia di laboratorium menjadi tantangan tersendiri dalam upaya peningkatan keterampilan laboratorium mahasiswa. Oleh karena itu, penting dilakukan pengembangan media video praktikum sebagai upaya memaksimalkan pengetahuan dan keterampilan kerja/praktikum di laboratorium dalam bentuk pengalaman pembelajaran audio visual (Tatli \& Ayas, 2013). Kelebihan media video seperti: dapat melatih mahasiswa untuk mengembangkan daya imajinasi yang abstrak, merangsang partisipasi aktif para mahasiswa, menyajikan pesan dan informasi secara serempak bagi seluruh mahasiswa, membangkitkan motivasi belajar, mengatasi keterbatasan ruang dan waktu, menyajikan laporan-laporan yang aktual dan orisinil yang sulit dengan menggunakan media lain dan mengontrol arah serta kecepatan belajar mahasiswa (Munadi, 2008, p. 39), merupakan pendekatan media yang tepat untuk menggantikan pengalaman praktikum di laboratorium.

Media video praktikum kimia perlu dikembangkan untuk mendapatkan video yang layak sebelum didistribusikan sebagai panduan/ modul bagi mahasiswa yang kurang mendapatkan pengalaman belajar di laboratorium. Pengembangan media sendiri merupakan metode penelitian yang digunakan untuk menghasilkan produk yang layak dengan cara menguji keefektifan produk tersebut (Agustina \& Novita, 2012). Menggunakan model 4D (define, design, develop, dan disseminate) yang dikembangkan oleh Thiagarajan, Semmel \& Semmel (tahun). Penelitian ini dibatasi pada tahap difine, design dan develop. Model pengembangan 4D mampu menghasilkan media pembelajaran seperti lembar kerja siswa (LKS) (Lestari \& Azizah, 2012; Riyani, Kusumo, \& Harjito, 2017). Dari beberapa keberhasilan penelitian pengembangan yang telah dilaksanakan dengan menggunakan model 4D, lebih lanjut model ini digunakan dalam pengembangan video pengenalan dan penggunaan alat gelas laboratorium kimia pada penelitian ini.

Tujuan penelitian ini adalah untuk menghasilkan video penggunaan alat gelas di laboratorium yang layak digunakan sebagai panduan mahasiswa program studi pendidikan kimia FKIP Universitas Khairun dalam melakukan praktikum. Dengan fokus pengembangan media video tentang pengenalan dan penggunaan alat gelas di Laboratorium Kimia.

\section{METODE}

Jenis penelitian ini adalah penelitian pengembangan (Research and Development) yang dilakukan di Program Studi Pendidikan Kimia FKIP Universitas Khairun, Ternate, Maluku Utara. Pengembangan media video pengenalan dan penggunaan alat gelas di laboratorium kimia menggunakan model 4D dengan tahapan seperti disajikan pada Gambar 1, diagram tahap pengembangan model 4D (Trianto, 2010). Tahap-tahap pengembangan media video penggunaan alat gelas di laboratorium yang digunakan merupakan adapatasi dari tahap pengembangan 4D diadaptasi dari Thiagarajan, yang meliputi empat tahap pengembangan yaitu define, design, develop, dan disseminate yang di kenal dengan nama 4-D. Adapaun tahapantahapannya yaitu: Tahap pendefenisian (define); tahap awal dalam penelitian yaitu analisis alatalat gelas yang digunakan dalam praktikum kimia. Tahap perancangan (design), pada tahap ini merancang skenario media video penggunaan alat gelas di laboratorium dalam bentuk naskah. Tahap pengembangan (develop), pada tahap ini, beberapa langkah yaitu: tahap pengambilan gambar, pada tahap ini dilakukan pengambilan 
gambar yang bertempat di laboratorium. Sedangkan tahap penyebaran (desseminate) dilaksanakan kepada mahasiswa semester I prodi pendidikan kimia FKIP Universitas Khairun tahun akademik 2017/2018.

Uji kelayakan video pengenalan dan penggunaan alat gelas di laboratorium kimia dengan diukur melalui uji validasi video dengan melibatkan 3 orang pakar di bidang media, pendidikan dan manajemen dan teknik laboratorium kimia dengan menggunakan teknik validitas data kepercayaan (Purwono, Yutmini, \& Anitah, 2014). Validasi media meliputi penilaian aspek: kelayakan isi, bahasa penyampaian, tampilan grafis dan penyampaian menggunakan penilaian skala 4 (Asmara, 2015). Sedangkan Uji keterbacaan dan keterlaksanaan dilakukan dengan metode angket serta observasi yang melibatkan 10 orang mahasiswa program studi pendidikan kimia FKIP Universitas Khairun.

\section{HASIL DAN PEMBAHASAN}

\section{Tahap Pendefinisian}

Tahap pendefinisian dalam alur pengembangan media video, dilakukan dengan menginventarisir alat gelas kimia di laboratorium yang biasa digunakan dalam praktikum kimia tahun I Prodi Pendidikan Kimia FKIP Universitas Kahirun. Mengingat praktikum kimia yang dilaksanakan pada tahun I di Prodi Pendidikan Kimia FKIP Universitas Kahirun, merupakan praktikum yang bertujuan meningkatkan keterampilan mahasiswa dalam mengenal, menggunakan dan mengorganisasi alat gelas di Laboraorium, maka proses inventarisasi alat gelas di Laboratorium difokuskan pada alat gelas kimia kelas A. Alat gelas kimia kelas A merupakan alat gelas kimia di Laboratorium yang kegunaannya diperuntukkan dalam preparasi kegiatan praktikum/penelitian kimia di Laboratorium. Pada tahap ini juga ditentukan banyaknya media video yang akan dikembangkan/diproduksi berdasarkan tujuan pengembangan media video.

\section{Tahap Perancangan}

Tahap perancangan pengembangan media video pengenalan dan penggunaan alat gelas kimia di laboratorium dimulai dari; pembuatan naskah/skrip/sekenario yang akan disajikan dalam video, pemilihan perangkat kamera dan lensa, software editor video, lokasi, hingga backsound video yang akan dikembangkan. Pelaksanaan tahap perancangan melibatkan tim peneliti dengan sejumlah mahasiswa untuk ditugaskan sebagai model, asisten pengambilan gambar/video hingga asisten editor video.

\section{Penulisan Naskah/Skrip/Sekenario Video}

Penulisan naskah/skenario video pengenalan dan penggunaan alat gelas kimia di laboratorium, merupakan kegiatan awal yang menjadi kunci hasil akhir produk video yang akan diproduksi dan dikembangkan nantinya. Naskah/ skenario video memuat ide cerita, tema dan judul, alur, seting tempat, properti serta model yang akan divideokan. Dimulai dengan menuliskan tema dan judul video yang akan diproduksi, skrip video disusun dengan menuliskan alur cerita yang akan divideokan.

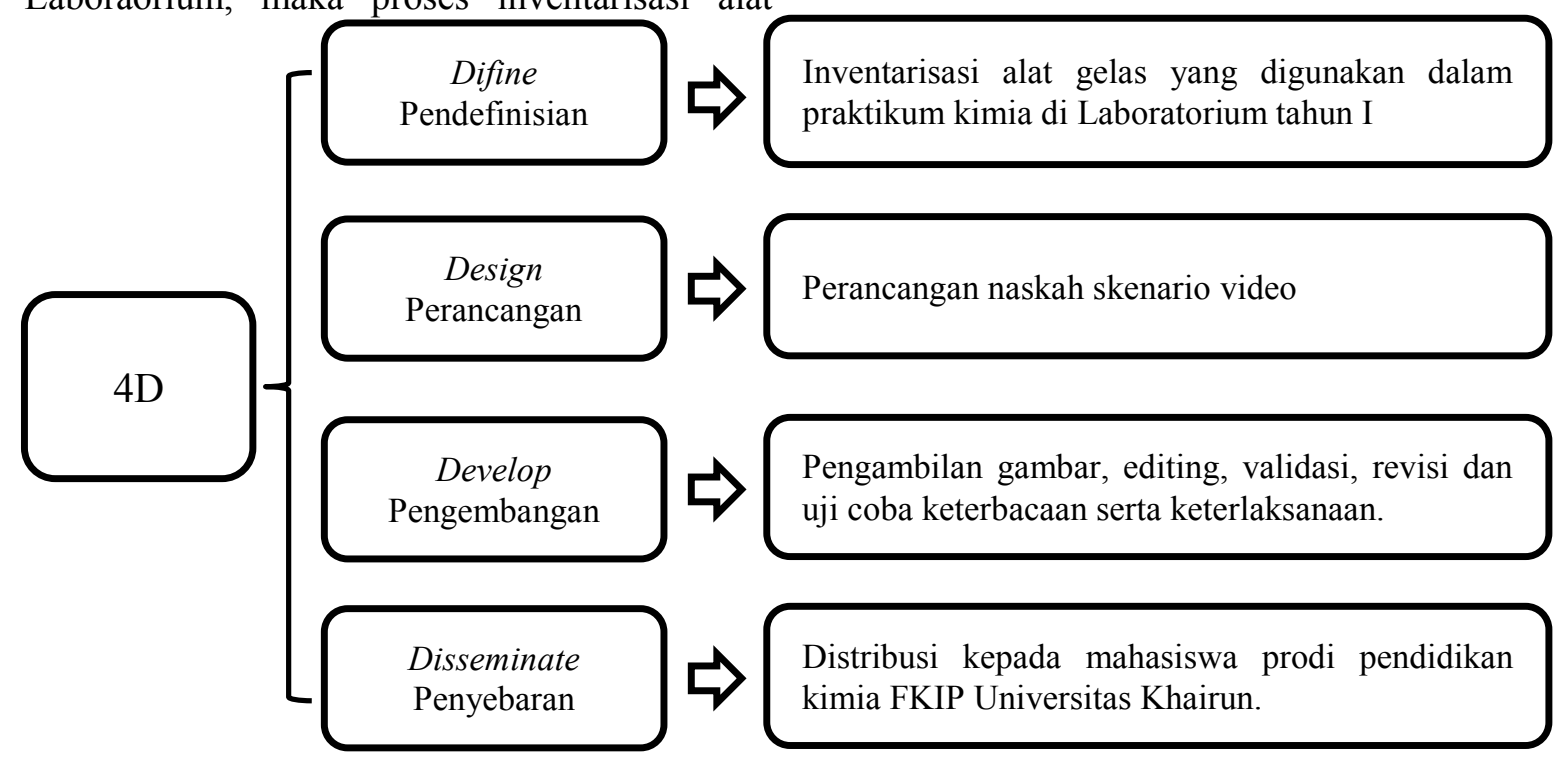

Gambar 1. Diagram Tahap Pengembangan Model 4D 
Penyusunan naskah/skenario video pengenalan dan penggunaan alat gelas di laboratorium kimia mengalami revisi/perbaikan untuk mendapatkan alur cerita yang sederhana namun informatif. Hal ini disesuaikan dengan tujuan pembuatan/pengembangan video sebagai media pembelajaran. Perubahan juga dilakukan pada skenario tampilan, yang awalnya menggunakan gambar foto alat gelas kimia, diubah menjadi gambar animasi alat gelas kimia. Perubahan skenario bentuk gambar ini dilakukan berdasarkan pertimbangan untuk lebih membuat menarik grafis tampilan media video yang akan diproduksi.

Alur cerita video pengenalan dan penggunaan alat gelas di laboratorium kimia diawali dengan tampilan judul video dengan background dasar putih. Tampilan judul menggunakan effek tulisan in dan out dengan tulisan berwarna biru, ukuran font 44 tipe adobe garam on pro bold. Slide selanjutnya dimulai dengan penampakan animasi alat gelas disebelah kiri halaman dengan nama alat tersebut pada bagian samping kanan atas menggunakan efek in dan out. Jumlah alat gelas yang diperkenalkan dalam video ini sebanyak 16 alat, yang kesemuanya merupakan gambar animasi. Setelah nama alat gelas berakhir disambung runing text penjelasan tentang kegunaan alat tersebut. Durasi tampilan setiap alat gelas dalam video tersebut rata-rata 17-21 detik. Pada bagian kedua, yakni video tentang penggunaan alat gelas yang telah diperkenalkan pada awal video. Video penggunaan alat gelas diawali dengan halaman pembuka yakni judul video. Dengan menggunkan efek dan font tulisan yang sama dengan bagian pertama, video ini dibuka dengan peragaan cara melipat kertas saring, penempatannya kedalam corong gelas dan metode filtrasi/penyaringan dengan teknik dekantasi yang diperankan oleh model. Fokus tampilan tata cara melipat kertas saring hingga metode filtrasi tertuju pada alat gelas yang digunakan dan peragaan tangan model saat melakukan praktikum. Pada bagian akhir video, tampilan berupa tulisan "terima kasih" menggunakan effek dan jenis font yang sama, dengan background warna hitam. Properti yang digunakan model dalam video ini antara lain, jas praktikum, sarung tangan karet, kacamata gogle dan masker.

\section{Pemilihan Lokasi}

Lokasi pengambilan gambar alat gelas dan praktikum penggunaan alat gelas kimia kelas A dilakukan di Laboratorium Lingkungan
FKIP Universitas Khairun. Pemilihan lokasi ini, didasarkan pertimbangan bahwa, ketersediaan meja praktikum yang proporsional, ketersediaan alat gelas kimia yang relatif lengkap, pencahayaan ruang laboratorium yang cukup bagus, serta kondisi ruangan yang bersih dan minimnya aktivitas non-akademis yang dapat mengganggu jalannya proses pengambilan gambar. Untuk lokasi editing gambar dan video dilakukan di ruang diskusi Laboratorium Lingkungan FKIP Universitas Khairun.

\section{Pemilihan Kamera}

Pemilihan perangkat kamera dan lensa kamera menjadi kegiatan penting dalam pengembangan media video pengenalan dan penggunaan alat gelas kimia di Laboratorium. Kamera yang dipilih dalam pengembangan media video ini adalah kamera tipe DSLR merk Nikon tipe D3300, dengan lensa yanga akan digunakan adalah lensa tipe objek fokus dengan ukuran diafragma 1,8D. Pertimbangan menggunakan kamera dan lensa ini adalah untuk mendapatkan hasil gambar yang berkualitas tinggi dengan resolusi fokus yang tajam. Disamping menggunakan kamera dengan lensa fokus, pengambilan gambar juga dilengkapi dengan 2 buah lampu TL modifikasi untuk mendapatkan kualitas gambar yang cerah.

\section{Pemilihan Perangkat Lunak (Software)}

Perangkat lunak (software) yang dipilih dan dipersiapkan untuk mendukung tampilan pada video diantaranya: software editor gambar dan animasi menggunakan Coreldraw, editor foto menggunakan Photosop, software background menggunakan Photoscape, editor video menggunakan AVS Video Editor dan software pemutar video menggunakan Windows Media Player. Semua perangkat lunak ini dipilih untuk mebuat tampilan dan alur video sesuai dengan skenario dengan kualitas visual yang menarik, tajam dan jelas.

\section{Pemilihan Backsound Video}

Musik instrumentasi dengan tempo sedang dipilih sebagai backsound video pengenalan dan penggunaan alat gelas kimia di Laboratorium. Dengan menambahkan backsound instrumental bertempo sedang, diharapkan dapat menambah minat dan semangat mahasiswa yang melihat video pengenalan dan penggunaan alat gelas kimia di Laboratorium. 


\section{Tahap Pengembangan Media Video}

Pengambilan Gambar

Proses pengambilan gambar dilakukan selama 3 bulan di Laboratorium Lingkungan FKIP Universitas Khairun. Dalam kegiatan ini dibagi dalam 2 bagian, bagian pertama adalah pengambilan gambar alat gelas kimia dan yang kedua adalah pengambilan gambar/video penggunaan alat gelas dalam praktikum di Laboratorium. Pengambilan gambar terdiri atas beberapa bagian gambar berdasarkan skenario yang diantaranya: (1) Pengambilan gambar berbagai macam alat gelas kimia tipe A untuk bahan video pengenalan alat gelas. Terdapat 20 alat gelas yang diambil gambarnya dan 16 alat yang ditampilkan dalam video dalam bentuk gambar animasi. Adapun 16 alat yang ditampilkan dalam video pengenalan alat gelas di Laboratorium tersebut diantarnya; tabung, reaksi, corong gelas, gelas arloji, cawan petri, pipet tetes, pipet volum, pipet gondok, labu takar, becker gelas, erlenmeyer, buret, filler, mortar dan pastle, bunsen, gelas ukur dan spatula. (2) Pengambilan video cara melipat kertas saring, (3) tata cara penimbangan bahan kimia padatan dan cair. (4) Teknik pelarutan bahan kimia padatan, (5) Teknik pengenceran, (6) teknik mencium bahan kimia dengan aman, (7) teknik pereaksian bahan kimia dengan pemanasan menggunakan bunsen, (8) teknik filtrasi dan dekantasi, serta (9) Teknik ekstraksi menggunakan corong pisah.

Pengambilan gambar dilakukan dengan metode cuting (segmentasi), yakni mengambil gambar pada durasi pendek, seperti teknik melipat kertas, dipisahkan dengan teknik melakukan filtrasi. Hal ini dilakukan untuk meminimalisir kesalahan tampilan, memudahkan dalam proses editing dan memberikan hasil gambar yang fokus serta berkualitas tinggi. Proses pengambilan gambar sangat memerlukan waktu yang cukup lama sekitar 70 hari. Hal ini dikarenakan dalam proses pengambilan video dilakukan dengan standar teknik laboratorium yang benar dan aman, serta untuk mendapatkan kualitas visual yang bagus dan tidak terkesan membosankan. Proses pengambilan gambar/video disajikan pada Gambar 2.

\section{Proses Editing Video}

Proses editing video dilakukan sebanyak 2 kali untuk menghasilkan video pembelajaran pengenalan dan penggunaan alat gelas laboratorium dalam praktikum kimia. Ada beberapa tahap dalam proses editing video, diantaranya: (1) Penggabungan video pendek, (2) Pembuatan cover, animasi gambar dan efek video, (3) Singkronisasi antar bagian video, (4) Pemasangan transisi video, (5) Penambahan backsound video dan, 6. Proses terakhir adalah converting format editing video ke format video.

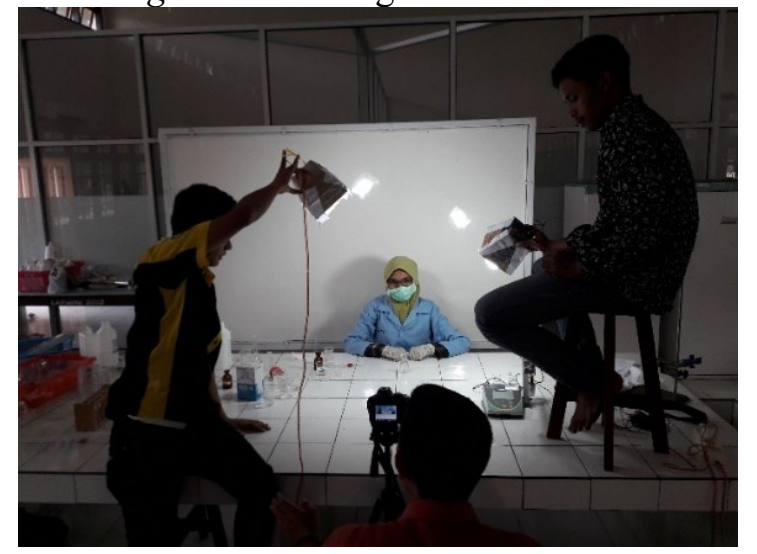

Gambar 2. Proses Pengambilan Gambar/Video

Penggabungan materi video pengenalan alat gelas di laboratorium dilakukan dengan menggabungkan 18 chapter video dari tampilan pembuka (judul) berjumlah 1 chapter, 16 chapter pengenalan dan kegunaan alat, serta 1 chapter penutup sebelum beralih di bagian ke dua yakni video penggunaan alat gelas di laboratorium. Sedangkan pada proses penggabungan chapter video penggunaan alat gelas di Laboratorium, dilakukan penggabungan sekitar 49 chapter video dari total 8 video teknik penggunaan alat gelas di laboratorium.

Proses penggabungan video dilakukan dengan cara memilih chapter video kemudian memasukkan beberapa chapter video terpilih dalam software AVS Video Editor. Proses pemasukkan dan penggabungan video dalam software AVS Video Editor tersaji pada Gambar 3.

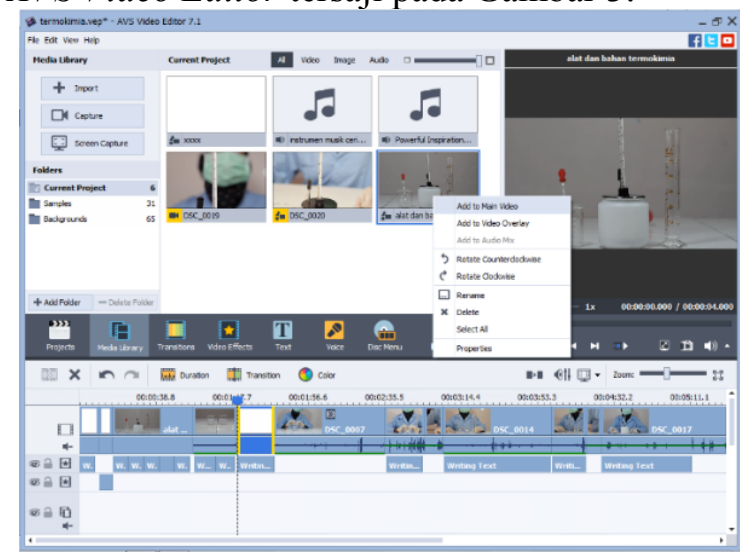

Gambar 3. Proses Pemasukkan dan

Penggabungan Video dalam Software AVS Video Editor 
Setelah video berhasil digabungkan, langkah selanjutnya adalah pembuatan halaman judul (cover), animasi gambar dan efek video. Pada tahapan pembuatan cover dikerjakan di software Photoscape. Pembuatan cover menggunakan software photoscape disajikan pada Gambar 4. Sedangkan penambahan efek in dan out pada judul video dikembangkan pada software induk AVS Video Editor.

Proses editing animasi gambar dikerjakan dengan corel draw $x 7$. Proses pembuatan animasi alat gelas dilakukan dengan menggambar kembali foto alat gelas yang ada. Sketsa hasil foto diberikan efek nyata dengan cara memberikan efek cahaya dan bayangan pada gambar animasi. Proses editing dari gambar foto menjadi gambar animasi yang berjumlah 16 gambar memerlukan waktu pengerjaan selama 20 hari. Selanjutnya, gambar animasi diekspor dalam format png untuk mendapatkan gambar tanpa background. Gambar animasi kemudian diberi tambahan nama alat dan diskripsi penggunaan pada software photoscape. Sedangkan efek video dikerjakan pada AVS Video Editor.

Proses singkronisasi bagian video dengan software AVS Video Editor, dikerjakan dengan cara menyesuaikan alur skenario dengan tampilan video. Dalam proses ini dilakukan pemilihan dan penyesuaian penempatan bagian video pada prototipe video. Penyesuaian video dengan alur skenario dilakukan untuk mendapatkan kualitas media pembelajaran yang komperhensif dan bersifat edukatif. Dengan penyesuaian alur skenario video, diharapkan mendapatkan video yang informatif yang dapat digunakan sebagai modul praktikum di laboratorium.

Tahap editing setelah didapatkan alur video sesuai skenario, maka selanjutnya adalah proses editing transisi video. Transisi video menjadi bagian penting dalam proses ini, karena dengan adanya transisi video dalam tampilan produk video nantinya, dapat mengurangi efek bumping atau tabrakan antara bagian video 1 dengan yang lain. Disamping juga proses ini diharapkan dapat memperhalus tampilan video secara keseluruhan.

Tahapan selanjutnya adalah penambahan musik instrumental sebagai backsound video. Penambahan musik ini dikerjakan diakhir proses editing video, dengan alasan untuk mempermudah proses penyelarasan antara tampilan dengan musik backsound yang ditambahkan. Proses penyelarasan dikerjakan dengan cara menyesuaikan durasi tampilan video dengan backsound musik yang ditambahkan. Durasi musik yang lebih pendek dibandingkan dengan tampilan video, akan dilakukan treatment pengulangan (repeat) bagian musik dengan cara memotong dan menambahkan potongan musik tersebut dalam kolom backsound video. Proses penambahan backsound instrumental musik disajikan pada Gambar 5.

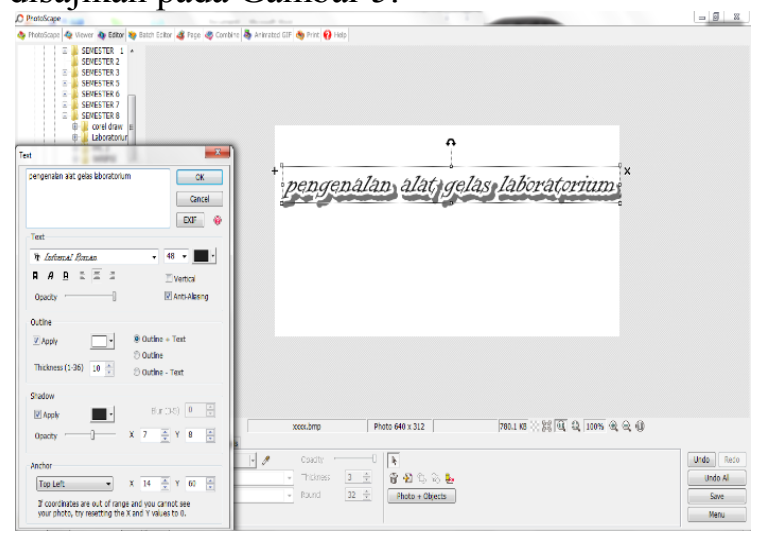

Gambar 4. Proses Pembuatan Cover Video

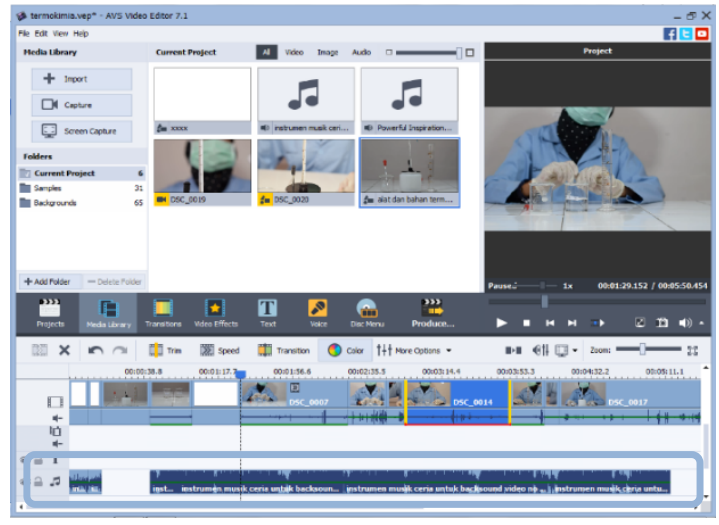

Gambar 5. Penambahan backsound video

Tahapan editing diakhiri dengan proses converting video. Proses ini merupakan penyelarasan video hasil edit dengan format aplikasi $A V S$ ke bentuk format video yakni MKV. Proses converting dilakukan agar media video dapat diputar/dimainkan pada aplikasi pemutar video seperti Windows Media Player dan lain sebagainya. Pada tahapan ini memang dibutuhkan waktu yang lumayan lama, hal ini dikarenakan proses tersebut dilakukan pada kualitas Hard Disk (HD) atau kualitas gambar yang besar. Kualitas gambar HD memerlukan kapasitas penyimpan memori yang cukup besar namun hasilnya dapat dinikmati dengan kualitas gambar yang jernih dan tajam. Tampilan hasil pengembangan video disajikan pada Gambar 6 .

\section{Validasi Media Video}

Tahapan setelah dihasilkannya protype video pembelajaran tentang pengenalan dan 
penggunaan alat gelas laboratorium kimia kelas A, adalah dengan memvalidasi prototype tersebut dengan metode validasi pakar. Validasi pakar dipilih dengan alasan untuk mendapatkan berbagai kritikan dan masukan dalam proses pengembangan prototype menjadi produk media video yang siap digunakan dalam pembelajaran mahasiswa Program Studi Pendidikan Kimia FKIP Universitas Khairun. Dalam proses validasi ini, dilaksakan dengan menunjuk 3 orang dosen yang dianggap pakar dalam, pendidikan, pengembangan media pembelajaran, dan pembelajaran di Laboratorium Kimia.

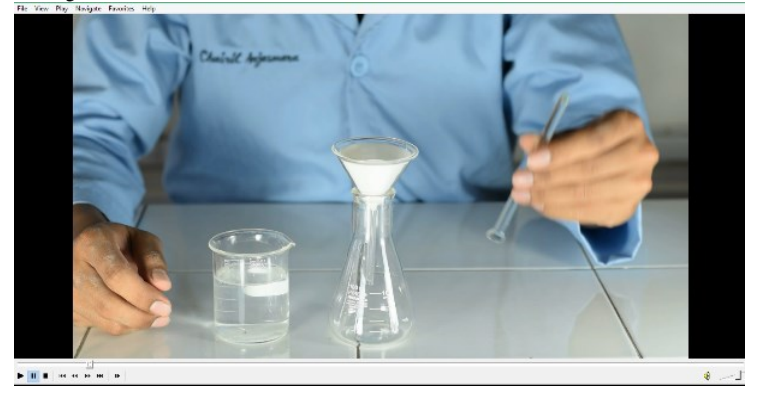

Gambar 6. Tampilan Prototype Video

Terdapat 4 aspek utama dalam penilaian validasi media video yang divalidasi oleh 3 orang pakar, diantaranya: (1) Kelayakan isi, (2) Bahasa penyampaian, (3) Grafis dan (4) Penyajian. Secara umum hasil validasi 3 orang pakar terhadap 4 aspek yang dikembangkan dalam video pengenalan dan penggunaak alat gelas laboratorium kelas A, disajikan seperti Gambar 7, diagram hasil validasi media video.

Dalam diagram hasil validasi media video secara umum yang ditunjukkan pada Gambar 7, dari 4 aspek utama yang dinilai. Penilaian media menggunkan skala 4. Secara rinci aspek yang divalidasi disajikan pada Tabel 1.

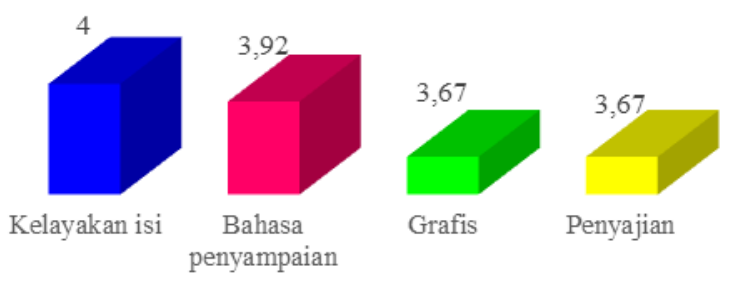

\section{Gambar 7. Diagram Hasil Validasi Video}

Berdasarkan Tabel 1, ditunjukkan bahwa aspek kelayakan isi dinyatakan sangat sesuai dengan indikator pembelajaran oleh semua validator dengan nilai rata-rata 4. Nilai 4 merupakan nilai tertinggi dari skala 4 yang menyatakan kategori sangat valid. Ini berarti media video yang dikembangkan sangat sesuai dengan capaian pembelajaran, khususnya pembelajaran keterampilan mahasiswa tahun I prodi pendidikan kimia FKIP Universitas Khairun.

Tabel 1. Hasil Validasi Kelayakan Isi Video

\begin{tabular}{lccc}
\hline \multicolumn{1}{c}{ Aspek } & V1 & V2 & V3 \\
\hline $\begin{array}{l}\text { Kesesuaian dengan indikator } \\
\text { pembelajaran }\end{array}$ & 4 & 4 & 4 \\
$\begin{array}{l}\text { Kesesuaian dengan kebutuhan } \\
\text { praktikum }\end{array}$ & 4 & 4 & 4 \\
$\begin{array}{l}\text { Kebenaran materi yang } \\
\text { disampaikan }\end{array}$ & 4 & 4 & 4 \\
$\begin{array}{l}\text { Kemudahan alat yang digunakan } \\
\text { Rata-rata }\end{array}$ & 4 & 4 & 4 \\
Kategori & Sangat valid \\
\hline V1-3: Validator 1-3 & & &
\end{tabular}

Aspek bahasa penyampaian media video pengenalan dan penggunaan alat gelas laboratorium kelas A, dinilai sangat valid dengan ratarata nilai validasi 3,92 dengan kategori sangat baik. Sedangkan hasil Validasi bahasa penyampaian disajikan pada Tabel 2. Dalam aspek bahasa penyampaian dalam video ini terdapat 4 indikator diantaranya: (1) Artikulasi penyampaian informasi, (2) Kejelasan informasi, (3) Kesesuaian dengan kaidah bahasa Indonesia, dan (4) Penggunaan bahasa yang efektif dan efisien. Dari ke-4 indikator dalam aspek bahasa penyajian, indikator artikulasi penyampaian informasi memiliki nilai validasi lebih rendah dibandingkan ketiga indikator lainnya, dengan nilai rata-rata sebesar 3,67. Sedangkan ketiga indikator lainnya memperoleh nilai sempurna dengan rata-rata skor 4.

Tabel 2. Hasil Validasi Bahasa Penyajian

\begin{tabular}{lccc}
\hline \multicolumn{1}{c}{ Aspek } & V1 & V2 & V3 \\
\hline Artikulasi penyampaian informasi & 3 & 4 & 4 \\
Kejelasan informasi & 4 & 4 & 4 \\
$\begin{array}{l}\text { Kesesuaian dengan kaidah Bahasa } \\
\text { Indonesia }\end{array}$ & 4 & 4 & 4 \\
$\begin{array}{l}\text { Penggunaan bahasa yang efektif dan } \\
\text { efesien }\end{array}$ & 4 & 4 & 4 \\
Rata-rata & \multicolumn{3}{c}{$\mathbf{3 , 9 2}$} \\
Kategori & \multicolumn{3}{c}{ Sangat valid } \\
\hline \multicolumn{1}{c}{ Grafis dalam media video dinilai dalam 4 }
\end{tabular}
aspek yang tersaji pada Tabel 3, hasil validasi aspek grafis. Aspek grafis mendapatkan nilai rata-rata 3,67 dengan kategori sangat valid. Aspek grafis dalam media video dinilai dalam 4 indikator, yakni; (1) Kualitas gambar/video, (2) Kualitas suara/sound, (3) Kualitas (jenis/ukuran) font, (4) Tempo/durasi video/gambar. Indikator kualitas gambar merujuk pada tingkat kejernihan, ketajaman, kejelasan serta singkronisasi pencahayaan dan warna tampilan video/gambar. 
Kualitas suara merujuk pada penilaian kualitas backsound musik dan suara instruksi kerja dalam video. Kualitas (jenis/ukuran) font mengacu pada kejelasan/keterbacaan, dan kesesuaian/artistik jenis font dalam media video. Sedangkan durasi video/gambar dinilai dari kesesuaian waktu/lama video ditampilkan perbagian dengan kecepatan keterbacaan penonton video dalam hal ini subjeknya adalah mahasiswa prodi pendidikan kimia FKIP Universitas Khairun.

Hasil validasi kualitas grafis media video menunjukkan bahwa kualitas warna dan suara mempunyai nilai sangat tinggi dengan rata-rata 4, ini berarti kualitas gambar (tampilan) dengan suara sangat representatif untuk media video pembelajaran. Sedangkan kualitas (jenis/ukuran) font dengan durasi menunjukkan nilai rata-rata 3,33. Hal ini menjadi bahan pertimbangan bahwa kualitas font dan durasi perlu dievaluasi dan diedit kembali.

Tabel 3. Hasil Validasi Aspek Grafis

\begin{tabular}{lccc}
\hline \multicolumn{1}{c}{ Aspek } & V1 & V2 & V3 \\
\hline Kualitas video/gambar & 4 & 4 & 4 \\
Kualitas suara & 4 & 4 & 4 \\
Kualitas (jenis dan ukuran) font & 3 & 3 & 4 \\
Tempo/durasi video atau gambar & 3 & 3 & 4 \\
Rata-rata & \multicolumn{3}{c}{$\mathbf{3 , 6 7}$} \\
Kategori & \multicolumn{3}{c}{ Sangat valid } \\
\hline
\end{tabular}

Sedangkan aspek penyajian video, hasil validasi pakar disajikan pada Tabel 4. Pada aspek penyajian video, nilai rata-rata hasil validasi sebesar 3,67 dengan kategori sangat valid. Aspek penyajian video dengan indikator penilaian terdiri atas; (1) Kejelasan judul/tema, (2) Kejelasan tujuan, (3) Daya tarik video dan gambar, (4) Kelengkapan penyajian. Dari 4 indikator yang ada, 2 indikator dinilai masih kurang dengan nilai rata-rata 3,33 dari skala 4 . Meskipun nilai ini dalam kategori tinggi, namun ke 2 indikator tersebut perlu dievaluasi dan diedit untuk meningkatkan kualitasnya. Kedua indikator yang perlu dievaluasi kembali diantaranya; daya tarik video dan gambar dan kelengkapan penyajian.

Tabel 4. Hasil Validasi Aspek Penyajian

\begin{tabular}{lccc}
\hline \multicolumn{1}{c}{ Aspek } & V1 & V2 & V3 \\
\hline Kejelasan judul/tema & 4 & 4 & 4 \\
Kejelasan tujuan & 4 & 4 & 4 \\
Daya tarik video/gambar & 3 & 3 & 4 \\
Kelengkapan penyajian & 3 & 4 & 3 \\
Rata-rata & \multicolumn{3}{c}{$\mathbf{3 , 6 7}$} \\
Kategori & \multicolumn{3}{c}{ Sangat valid } \\
\hline \multicolumn{2}{c}{ Secara keseluruhan } & \multicolumn{2}{c}{ hasil validasi } \\
prototype media video pengenalan dan
\end{tabular}

penggunaan alat gelas laboratorium memiliki nilai rata-rata sebesar 3,81 dari skala 4 dengan kategori sangat valid. Dengan hasil ini menunjukkan bahwa media video ini layak untuk di uji cobakan pada kelas terbatas. Namun sebelum dilakukan uji coba terbatas pada aspek keterbacaan media di mahasiswa prodi pendidikan kimia FKIP Universitas Khairun tahun angkatan 2016, media video dilakukan revisi editing video berdasarkan rujukan hasil validasi.

\section{Revisi Editing Media Video}

Proses revisi editing video pengenalan dan penggunaan alat gelas laboratorium dikerjakan untuk meningkatkan kualitas media video. Revisi ini lebih difokuskan pada singkronisasi durasi, kualitas font dan tampilan gambar untuk meningkatkan daya tarik video/gambar. Pada revisi editing media video, beberapa yang diubah antara lain; tampilan foto alat gelas laboratorium diubah menjadi tampilan gambar animasi alat gelas. Selain untuk meningkatkan daya tarik tampilan, hal ini juga dimaksudkan untuk memberikan rangsang imajinasi gambar alat terhadap pemirsanya.

Edit video yang dilakukan pada jenis font adalah dengan mengganti jenis font dari jenis adobe garam and pro bold ke informal penan. Karakteristik jenis tampilan tulisan hasil editing diharapkan lebih jelas sehingga mudah untuk dibaca namun mempunyai aksen artistik untuk mendukung tampilan video.

Sedangkan durasi video, pada awal mula hasil penggabungan video, durasi yang dihasilkan adalah sekitar 21 menit, namun setelah dilakukan pengeditan, durasi video mampu diperpendek menjadi 18 menit. Pemotongan durasi ini dimaksudkan untuk membuat video lebih berisi dan tidak membosankan bagi pemirsanya. Proses memperpendek durasi video pengenalan dan penggunaan alat gelas di laboratorium dilakukan dengan mempercepat dan memotong beberapa chapter video pada peragaan teknik laboratorium dalam meggunakan alat gelas di Laboratorium. Proses mempercepat peragaan/ praktikum penggunaan alat gelas dilakukan pada bagian proses penyaringan, khususnya pada bagian penyusunan rangkaian alat gelas seperti corong gelas, erlenmeyer dan pengaduk kaca. Adapaun proses pemotongan pada chapter ini dilakukan pada bagian proses penuangan larutan ke dalam corong gelas. Proses percepatan durasi video juga dilakukan pada chapter pelarutan padatan bahan kimia pada larutannya, penuangan larutan dalam labu takar, proses pengenceran 
dan proses ekstraksi pelarut menggunakan corong pisah. Upaya mempercepat dan pemotongan video yang dilakukan ternyata mampu menurunkan durasi video selama 3 menit.

Hasil evaluasi aspek daya tarik gambar difokuskan pada tampilan foto gambar alat gelas yang pada slide dengan keterangan nama dan deskripsi penggunaan alat yang menyebabkan tampilan video kurang menarik. Proses edit dilakukan dengan mengganti semua gambar foto alat gelas dengan animasi alat gelas, serta penyelarasan background dengan tampilan gambar animasi tersebut. Deskripsi gambar animasi alat gelas hasil edit foto yang dikerjakan dengan bantuan software corel draw $x 7$, yakni berupa gambar seketsa dengan dominasi warna putih, sehingga mampu menyesuaikan dengan background yang akan digunakan. Efek pencahayaan diberikan warna gradasi putih ke abuabu yang mempunyai karakteristik senada dengan background tampilan, dengan aksen bayangan untuk membuat gambar menjadi lebih hidup dan menarik. Salah satu tampilan chapter video yang disajikan pada Gambar 8, menunjukkan tampilan pengenalan alat gelas yang telah diedit menjadi tampilan gambar animasi.

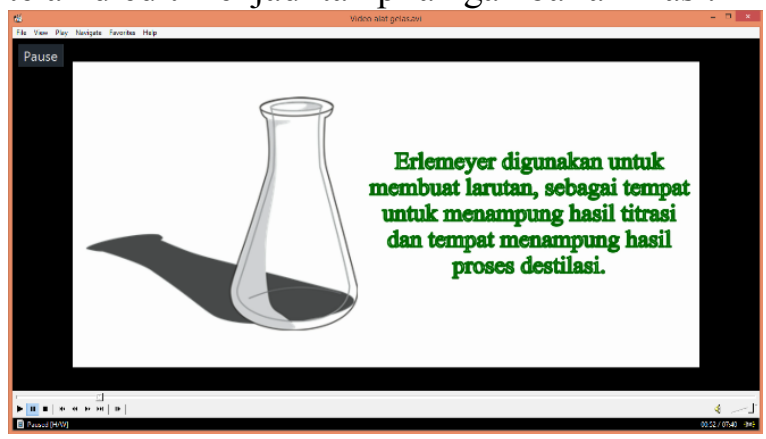

Gambar 8. Tampilan Animasi Alat Gelas

Hasil Uji Keterbacaan Media Video

Uji keterbacaan media video dilakukan dengan memutarkan video pengenalan dan penggunaan alat gelas laboratorium pada 10 mahasiswa program studi pendidikan kimia FKIP Universitas Khairun. Setelah pemutaran video yang ada, setiap mahasiswa diminta memberikan respon keterbacaan media video dengan cara mengisi angket yang telah diberikan. Dalam angket uji keterbacaan tersebut, terdapat 9 aspek yang dinilai diantaranya; (1) kejelasan pengantar, (2) kejelasan petunjuk/ instruksi, (3) kejelasan bahasa, (4) kejelasan video/gambar, (5) kemenarikan ilustrasi video/ gambar, (6) kejelasan alur praktikum, (7) keterbaruan informasi, (8) kesesuaian materi dengan tujuan, dan (9) keterkaitan video dengan materi.
Hasil uji keterbacaan media video disajikan pada Gambar 9, diagram hasil uji keterbacaan media video.

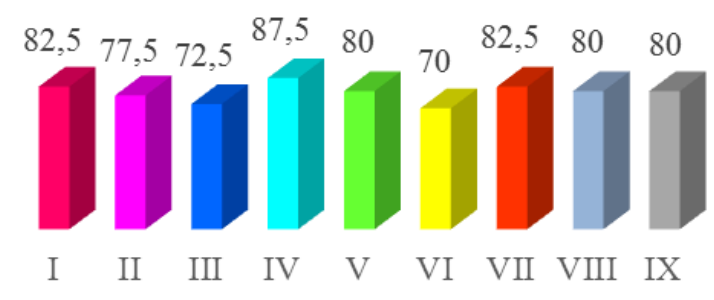

Gambar 9. Diagram Hasil Uji Keterbacaan Video (Ket; I-IX = aspek 1-9)

Dari 9 aspek yang dinilai, uji keterbacaan secara umum menunjukkan persentase sebesar $79,17 \%$, yang berarti media video pengenalan dan penggunaan alat gelas laboratorium mampu terbaca dengan baik oleh mahasiswa prodi pendidikan kimia FKIP Universitas Khairun. Keterbacaan paling tinggi dengan persentase $87,5 \%$ adalah pada aspek kejelasan video/ gambar. Hal ini merujuk pada kualitas video/ gambar yang ditampilkan. Produk video pengenalan dan pengguanaan alat gelas di Laboratorium berkapasitas $728 \mathrm{MB}$, kapasitas tersebut cukup besar dengan durasi video 18 menit. Persentase tertinggi kedua hasil keterbacaan sebesar $82,5 \%$ untuk aspek I tentang kejelasan pengantar dan VII keterbaruan invormasi. Aspek kejelasan pengantar mencakup kesesuaian judul video dengan isi materi dalam video tersebut. Dalam produk video tersebut ada dua chapter pengantar antara lain; pengenalan dan penggunaan alat gelas di Laboratorium. Pada video bagian I, dengan pengantar pengenalan alat gelas di Laboratorium, materi tampilan video berisi 16 chapter gambar alat gelas yang dilengkapi dengan keterangan nama serta deskripsi penggunaan alat tersebut dengan durasi sekitar 7 menit. Bagian video II, yang berisi materi tentang penggunaan alat gelas di Laboratorium terdiri atas 7 chapter dengan durasi sekitar 11 menit. Aspek kemenarikan ilustrasi gambar/video, kesesuaian materi dengan tujuan praktikum dalam video dan kesesuaian materi dengan isi video, masing-masing mempunyai nilai keterbacaan sebesar $80 \%$. Hal ini mengindikasikan bahwa upaya mengubah tampilan dari foto menjadi gambar animasi alat gelas mendapatkan respon positif dari sebagian besar mahasiswa, disamping juga adanya kejelasan serta kesesuaian tujuan dan materi dengan 
isi/tampilan video pengenalan dan penggunaan alat gelas di Laboratorium.

Aspek kejelasan petunjuk/instruksi dan kejelasan bahasa dalam video, mendapatkan respon nilai keterbacaan sebesar $77,5 \%$ dan $72,5 \%$. Aspek kejelasan petunjuk/instruksi merujuk pada pernyataan instruktif dalam praktikum pada tampilan di video sedangkan aspek kejelasan bahasa mencakup penggunaan bahasa dalam video tersebut. Kedua aspek tersebut dalam video pengenalan dan penggunaan alat gelas di Laboratorium terbatas pada keterangan deskriptif tentang nama dan kegunaan alat gelas, sehingga pernyataan yang bersifat instruktif jarang ditemui dalam video tersebut. Sedangkan aspek terendah dari uji keterbacaan video tersebut adalah pada kejelasan alur praktikum, dengan persentase keterbacaan sebesar $70 \%$. Hal ini kami anggap wajar, karena memang video ini bukan merupakan modul praktikum resmi di Laboratorium, namun merupakan video pengenalan dan penggunaan alat gelas laboratorium sebagai pendukung modul praktikum dari bagian kecil dari keterampilan praktikum di Laboratorium.

\section{Hasil Uji Keterlaksanaan}

Uji keterlaksanaan dilaksanakan untuk mengetahui kemampuan media video pengenalan dan penggunaan alat gelas laboratorium dapat memberikan informasi yang komperhensif kepada mahasiswa prodi pendidikan kimia FKIP Universitas Khairun. Keterlaksanaan terkait mengenali, menggunakan, melaksanakan praktikum hingga mengorganisasi alat gelas laboratorium dalam praktikum kimia di laboratorium, menjadi aspek penting yang diamati dalam uji keterlaksanaan ini. Teknis dalam pengujian ini, dilaksanakan dengan melakukan observasi praktikum kepada 10 mahasiswa prodi pendidikan kimia FKIP Universitas Khairun setelah melihat video praktikum pengenalan dan penggunaan alat gelas laboratorium. Hasil observasi dituliskan dalam nilai skala 4 pada lembar observasi. Hasil uji keterlaksanaan disajikan pada Gambar 10, diagram hasil uji keterlaksanaan media video. Berdasarkan diagram keterlaksanaan media video, terlihat bahwa persentase tertinggi keterlaksanaan video pengenalan dan penggunaan alat gelas laboratorium sebesar $90 \%$ adalah pada aspek kemampuan mengenali alat gelas (I), disusul aspek mengorganisasi alat gelas (IV) sebesar 70\%, kemampuan menggunakan alat gelas (II) $60 \%$ dan persentase paling rendah sebesar 50\% merupakan aspek kemampuan melaksanakan praktikum sesuai tujuan/ilustrasi kerja (III). Persentase keterlaksanaan total dari 4 aspek yang diukur dalam memberikan pemahaman terhadap kemampuan/ keterampilan yang bisa dilaksanakan secara langsung di laboratorium oleh mahasiswa kimia prodi pendidikan kimia FKIP Universitas Khairun sebesar $67,50 \%$.

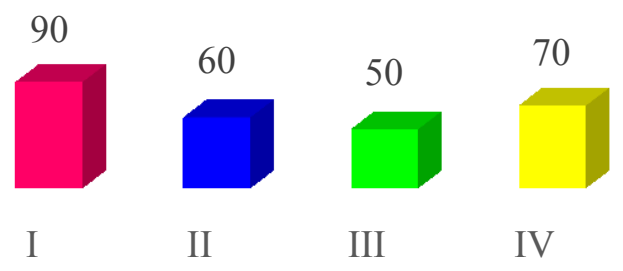

Gambar 10. Diagram Hasil Uji Keterlaksanaan Video

\section{Tahap Penyebaran (Disseminate)}

Video hasil pengembangan disebarluaskan kepada mahasiswa baru tahun akademik 2017/2018 Program Studi Pendidikan Kimia FKIP Universitas Khairun. Pelaksanaan penyebarluasan dilakukan pada proses perkuliahan Praktikum Kimia Dasar I pada pertemuan perdana. Penyebarluasan ini dimaksudkan agar mahasiswa program studi pendidikan kimia FKIP Universitas Khairun Tahun ajaran 2017/ 2018 lebih siap dalam melaksanakan kegiatan praktikum kimia di Laboratorium.

\section{SIMPULAN}

Telah dilakukan pengembangan video pengenalan dan penggunaan alat gelas laboratorium dengan durasi 18 menit. Kedua video tersebut dinyatakan layak dengan nilai validitas media sebesar 3,81 dengan kategori sangat baik, persentase keterbacaan sebesar $79,17 \%$ dan persentase keterlaksanaan sebesar $67,50 \%$.

\section{DAFTAR PUSTAKA}

Agustina, A., \& Novita, D. (2012). Pengembangan media pembelajaran video untuk melatih kemampuan memecahkan masalah pada materi larutan asam basa. UNESA Journal of Chemical Education, 1(1).

Asmara, A. P. (2015). Pengembangan media pembelajaran berbasis audio visual tentang pembuatan koloid. Jurnal Ilmiah Didaktika, $\quad 15(2), \quad 156$. https://doi.org/10.22373/jid.v15i2.578

Hofstein, A., \& Mamlok-Naaman, R. (2007). 
The laboratory in science education: the state of the art. Chemistry Education Research and Practice, 8(2), 105-107.

Ismail, O. M. S. (2016). Green approach for chemical education in chemistry lab. American Journal of Chemistry, 6(2), 5559.

https://doi.org/doi:10.5923/j.chemistry.20 160602.05

Lestari, A., \& Azizah, U. (2012). Development of science-chemitry student workheet oriented somatic, auditory, visual, and intellectual (SAVI) in the topic matter changes for junior high school. Unesa Journal of Chemical Education, 1(1), 4146.

Munadi, Y. (2008). Media pembelajaran (Sebuah pendekatan baru). Jakarta: Bumi Aksara.

Purwono, J., Yutmini, S., \& Anitah, S. (2014). Penggunaan media audio-visual pada mata pelajaran ilmu pengetahuan alam di Sekolah Menengah Pertama Negeri 1
Pacitan. Jurnal Teknologi Pendidikan Dan Pembelajaran, 2(2). Retrieved from http://www.jurnal.fkip.uns.ac.id/index.ph $\mathrm{p} / \mathrm{tp} /$ article/view/3659

Riyani, A. F., Kusumo, E., \& Harjito, H. (2017). Pengembangan lembar kerja siswa berpendekatan inkuri terbimbing pada konsep kelarutan. Jurnal Inovasi Pendidikan Kimia, 11(2). Retrieved from https://journal.unnes.ac.id/artikel_nju/JIP $\mathrm{K} / 10626$

Tatli, Z., \& Ayas, A. (2013). Effect of a virtual chemistry laboratory on students' achievement. Educational Technology \& Society, 16(1), 159-170. Retrieved from http://www.ifets.info/journals/16_1/14.pd $\mathrm{f}$

Trianto, T. (2010). Mendesain model pembelajaran inovatif-progresif: konsep, landasan, dan imlementasinya pada kurikulum tingkat satuan pendidikan (KTSP). Jakarta: Kencana. 